\title{
Effect of Germination on the Nutritional and Anti-Nutritional Composition of Soy Bean (Glycine max)
}

\author{
Harmeen Kaur and Navjot Kaur* \\ Department of Food and Nutrition, College of Community Science, Punjab Agricultural \\ University, Ludhiana, India \\ *Corresponding author
}

\section{A B S T R A C T}

Keywords

Proximate composition, Amino acids, Minerals, Antinutritional factors, Germinated soybean

Article Info

Accepted: 07 July 2019 Available Online: 10 August 2019
Soybean (Glycine max) is a superior plant food known as miracle golden bean for its treasure trove of economical and preeminent protein than the high-priced meat protein. Soybean is not only known for its nutritional components but also provides significant health related benefits. This study was planned to analyze the effect of processing of soybean on its nutritional composition. Raw seeds with and without seed coats and germinated forms of three soybean varieties were analyzed for its nutritional and anti-nutritional components. Significant changes were observed during processing of the soybean seeds. Seeds when germinated contained 40.05-46.46 percent protein in SL 525, SL 744 and SL 958 soybean varieties and increase in amino acid namely lysine $(5.70 \mathrm{mg} / 100 \mathrm{~g})$, methionine $(0.61 \mathrm{mg} / 100 \mathrm{~g})$ and tryptophan $(1.11 \mathrm{mg} / 100 \mathrm{~g})$ was recorded highest in SL 958. Minerals like potassium, calcium, magnesium and phosphorus were reported to increase significantly during germination. With germination, there was an increase in in vitro protein digestibility with decrease in anti-nutritional factors like trypsin inhibitor and total phenols.

\section{Introduction}

Soybean (Glycine max) is considered as an important grain legume that belongs to species of legume which is categorized under the family 'Leguminosae' with sub family 'Papilionaceae' native to East and South-East Asia. It is commonly produced and consumed in tropical and subtropical regions of the world. Soybean is mostly found in Southeast Asia. It is a widely grown valuable crop in the central part of India where the bulk is utilized for producing oil or for animal feed, while considerably small usage for human or direct consumption which is increasing steadily (Singh, 2016). It is superior to all other plant food because it has a good balance of all essential amino acids and contains proper amount of methionine. Soybean is therefore, not only known for its nutritional components but also provides significant health related benefits. Soybean is known as miracle golden bean. Soybean protein is economical and preeminent than the high-priced meat protein 
and so it is considered as the best source of protein in a vegetarian diet. Considering its nutritional attributes, mainly its high protein and fat content provided with the significant potential for cost-effective improvement of daily diets, helps in substantial reduction of protein-energy malnutrition (Goel et al., 2018). It contains good amount of essential macro nutrients for regulating good nutrition which includes protein (40\%), carbohydrates $(18 \%)$ and fat (18\%). The moisture content is 9 percent and fibre is 10 percent with other micro nutrients (5\%) like folic acid, calcium, potassium and iron (Singh 2009).

Protein content is $30-45$ percent with a good source of all indispensable amino acids with a digestibility value of 91.41 percent. The protein content is six times more than the rice grains and four times higher than the wheat. (Serrem et al., 2011).

Germination is done to boost the nutritive value and to inactivate the anti-nutritional components or the undesirable substances namely trypsin inhibitors, phytic acid, oligosaccharides and components with lipoxygenase activity that is present in it (Ramadan 2012). It is an effective and valueadded technological approach in order to enhance the nutritional quality of soybeans in Asian countries due to its digestibility (Cho et al., 2009).

Germination is done in order to enhance its nutritional value which results in enriched soy flour in various nutrients, increasing its utilization and versatility as compared to the non-germinated flour. During germination, the protein content of soy flour was 6.90 percent higher with increase in essential amino acid content of mainly lysine, valine and threonine by $8.53,8.50$ and 7.93 percent. In addition, there was an increase in the iron and vitamin B2 content by 14.29 percent and 8.80 percent respectively as compared to the non- germinated soy flour. Germinated soy flour contained $77.06 \mu \mathrm{g} / 100 \mathrm{~g}$ vitamin A, $0.29 \mu \mathrm{g} / 100 \mathrm{~g}$ vitamin $\mathrm{B}$, and $0.32 \mu \mathrm{g} / 100 \mathrm{~g}$ vitamin $\mathrm{B}_{2}$ (Rahman et al., 2016).

So, considering the properties of soybean, the present study was planned with the objective to determine the effect of processing on the nutritional composition of soybean.

\section{Materials and Methods}

\section{Procurement and processing of soybean varieties}

The sample of soybean seeds of three varieties- SL 525, SL 744 and SL 958 were procured from Department of Plant Breeding and Genetics, College of Agriculture, Punjab Agricultural University, Ludhiana. Soybean seeds were sorted based on size, colour and then thoroughly washed with water to remove any residues from the seed surface along with dirt or any other foreign material. After surface cleaning, the seeds were soaked in warm distilled water for 16-18 hours. The germination process was induced such that the seeds were placed (wrapped tightly) in sterilized wet cotton muslin cloth at room temperature in dark conditions, away from direct sunlight. The seeds were left to germinate for about 24 hours. The cloth was kept moist to support the germination process. After germination, the grains were boiled for 1 hour to reduce antinutritional factors. The seeds were later dried at $60^{\circ} \mathrm{C}$ up to 10 percent moisture content using mechanical dryer. The dried soybean seeds were de-vegetated and grinded to make germinated soybean flour. The flour was stored and packed in air tight plastic bags for further analysis.

\section{Proximate analysis}

Flour of raw soybean seeds with and without seed coat and of geminated soybean seeds 
were analyzed for their proximate composition namely moisture, crude protein, crude fibre, crude fat and total ash by (AOAC 2000) method. The total available carbohydrate was calculated by difference of total contents from 100.

\section{Amino acid content}

The content of amino acid present in soybean (raw and germinated) were analyzed such that, tryptophan was estimated with procedure given by Concon (1975), methionine by Horn et al., (1946), cysteine by Liddell and Saville (1959) and available lysine by Carpenter (1960) modified by Booth (1971).

\section{Mineral content}

Minerals like potassium, calcium, phosphorus, magnesium and zinc were estimated by atomic absorption spectrophotometer.

\section{In vitro protein digestibility}

In vitro protein digestibility of soybean samples was estimated by method used by Akeson and Stachman (1964).

\section{Anti-nutritional components}

Anti-nutritional components like trypsin inhibitors and total phenols were analyzed. (Roy and Rao, 1971).

\section{Statistical analysis}

Samples for all the determinations were carried out in triplicates and results were expressed as mean + standard deviation. The data was analyzed with the help of statistical tools. To test the significant difference between raw and germinated samples, ANOVA was applied using SPSS16.0 software. The significant difference was carried out at $5 \%$ level of significance.

\section{Results and Discussion}

\section{Proximate composition}

The proximate composition of different soybeans varieties in the form of germinated (G), non-germinated without seed coat (NGSC) and non-germinated with seed coat (NGWSC) were analyzed on their dry weight basis and have been presented in Table 1. The proximate content of different varieties showed significant variability with respect to moisture, protein, fibre, ash content and carbohydrates. The moisture content was highest in NGSC with 4.73 percent and lowest in $\mathrm{G}$ with 1.74 percent of SL 744 variety. The percent crude protein content of $\mathrm{G}$ was highest in SL 958 i.e. 46.46 percent. No significant difference was observed among the NGWSC varieties, lowest protein was recorded in SL 525 with 36.05 percent Warle et al., (2015) studied the effect of germination on nutritional quality of soybean. Germination of grains increased the moisture content upto 10 percent to 11 percent from 1 percent, total sugars from 3.55 percent to 5.6 percent, protein content also increased from 29.09 percent to 34.99 percent Torres et al., (2006) reported that soybeans contain about 35-40 percent of the protein on a dry weight basis. Crude protein increased with increase in days germination when compared to raw control group. The protein content was increased to 6.90 percent in germinated soy flour. This finding was similar to the other study done by (Ugwuona et al., 2012) and (Nwosu et al., 2014).

The fibre content of NGSC was recorded highest in SL 958 i.e.18.24 percent and lowest observed in NGWSC of SL 744 (7.28\%). Martino et al., (2011) presented the chemical composition and iron bioavailability based on rats when provided them soybean flour with and without hulls. It was found that soybean hull flour contained 37 percent more total dietary fibre and a higher content of iron than 
that of the soybean flour without hull. The crude fat content was significantly highest in SL 958 of NGSC soybean and lowest in SL 525 of $\mathrm{G}$ seeds with 20.32 and 8.31 percent fat respectively. Ghavidel and Prakash (2007) reported that there was a significant decrease in the fat content of some legume seeds after the seeds were germinated. Osman (2007) conducted a study in which there was a significant decrease in the fat content of germinated seeds with time period of 3 days supporting the process with use of fat as energy.

The percentage of total ash of NGSC was highest in SL 525 with 5.66 percent and lowest observed in G of SL 744 with 3.51 percent. Ari et al., (2012) reported that the ash content of thermal treated soybean varied from 4.27 to 4.46 per cent. The carbohydrate content of Germinated SL 525 was reported highest with $35.91 \mathrm{~g}$ whereas lowest observed carbohydrate content was found in NGSC of SL 958 with $13.91 \mathrm{~g}$.

Warle et al., (2015) reported that the carbohydrate content of soybean was significantly decreased after soaking, germination and heating treatments i.e. 22.10 to 17.90 percent as observed in other two varieties i.e. SL 744 and SL 958Furthermore, the fat content was reduced from 24 percent to 10 percent and ash content from 4.95 percent to 4.59 percent.. The energy content was low in $\mathrm{G}$ seeds of SL 525 i.e. $378 \mathrm{Kcal}$ whereas high of SL 958 in NGWSC (419 Kcal).

Effects of traditional processing methods on the nutritional and anti-nutritional properties of soybean were analysed by Pele et al., (2016). Soybeans were subjected to various handling strategies which were mainly sun drying and processing. Sample A was considered as the controlled sample where the soybean seeds were subjected to sun for drying and then milled. For sample B, soybean was drenched for 24 hours then it was sun dried and processed. For test $\mathrm{C}$, it was almost similar to sample B but it was soaked for 12 hours instead of 24 hours which was later dehulled, sun dried and further subjected to processing. For the last sample $D$, the soybeans were sprouted for 120 hours, then they were sun dried and later processed. Proximate composition of soybean revealed that protein content of the samples increased from 23.98 percent to 28.44 percent with a noteworthy increment in sample B, sample C and sample D.

The fat content increased from 20.51 percent to 26.20 percent while crude fibre varied from 4.68 percent to 6.58 percent. The moisture content extended from 7.23 percent to 10.92 percent had demonstrated a critical lessening in the control.

\section{Amino acids}

The data on the amino acid content of germinated and raw seeds is presented in Table 2. Lysine content of G seeds of SL 958 reported to be the highest with $5.70 \mathrm{mg}$ and lowest was observed $4.63 \mathrm{mg}$ in SL 744 of NGWSC treated seeds. Highest cysteine content of SL 744 in G treated seeds was 0.15 mg whereas no significant difference was observed in NGWSC and NGSC treated seeds. The methionine content of SL 958 was reported to be highest in $\mathrm{G}$ seeds with $0.61 \mathrm{mg}$ and lowest in NGWSC of SL 525 with 0.22 mg. G seeds of SL 958 recorded highest tryptophan content of $1.11 \mathrm{mg}$ and lowest in SL 744 of NGSC with $0.40 \mathrm{mg}$. Hallen et al., (2004) reported that amino acids and available vitamins were increased during germination. Rahman et al., (2016) studied essential amino acids content including threonine $(3.13 \%)$, lysine $(2.29 \%)$, valine $(0.51 \%)$, glutamic acid $(1.28 \%)$, isoleucine $(1.49 \%)$ and methionine $(1.28 \%)$ were found higher in germinated soy flour as compared to raw soy flour. 
Table.1 Proximate composition of raw and germinated soybean (on dry weight basis)

\begin{tabular}{|c|c|c|c|c|c|c|c|c|c|}
\hline \multirow{3}{*}{ Proximate Composition } & \multicolumn{3}{|c|}{ SL 525} & \multicolumn{3}{|c|}{ SL 744} & \multicolumn{3}{|c|}{ SL 958} \\
\hline & \multicolumn{2}{|c|}{ Non- Germinated } & \multirow[b]{2}{*}{ Germinated } & \multicolumn{2}{|c|}{ Non-Germinated } & \multirow[b]{2}{*}{ Germinated } & \multicolumn{2}{|l|}{ Non-Germinated } & \multirow[b]{2}{*}{ Germinated } \\
\hline & $\begin{array}{l}\text { With seed } \\
\text { coat }\end{array}$ & $\begin{array}{l}\text { Without } \\
\text { seed coat }\end{array}$ & & $\begin{array}{l}\text { With seed } \\
\text { coat }\end{array}$ & $\begin{array}{l}\text { Without seed } \\
\text { coat }\end{array}$ & & With seed coat & $\begin{array}{l}\text { Without seed } \\
\text { coat }\end{array}$ & \\
\hline Moisture (\%) & $3.76^{\mathrm{aB}} \pm 0.03$ & $3.39^{\mathrm{aB}} \pm 0.18$ & $2.04^{\mathrm{aA}} \pm 0.03$ & $4.73^{\mathrm{bB}} \pm 0.24$ & $4.22^{\mathrm{bB}} \pm 0.11$ & $1.74^{\mathrm{aA}} \pm 0.08$ & $4.34^{\mathrm{bB}} \pm 0.06$ & $4.29^{\mathrm{bB}} \pm 0.21$ & $2.32^{\mathrm{aA}} \pm 0.74$ \\
\hline Crude protein (\%) & $38.59^{\mathrm{aA}} \pm 1.11$ & $36.05^{\mathrm{aA}} \pm 2.47$ & $40.05^{\mathrm{aA}} \pm 0.99$ & $40.25^{\mathrm{abA}} \pm 0.74$ & $38.59^{\mathrm{aA}} \pm 2.1$ & $42.50^{\mathrm{aA}} \pm 0.74$ & $42.53^{\mathrm{bAB}} \pm 0.74$ & $40.51^{\mathrm{aA}} \pm 1.11$ & $46.46^{\mathrm{bB}} \pm 2.85$ \\
\hline Crude fat $(\%)$ & $17.98^{\mathrm{aC}} \pm 0.23$ & $12.96^{\mathrm{aB}} \pm 0.08$ & $8.31^{\mathrm{aA}} \pm 0.33$ & $18.50^{\mathrm{bC}} \pm 0.06$ & $13.66^{\mathrm{bB}} \pm 0.21$ & $9.50^{\mathrm{bA}} \pm 0.5$ & $20.32^{\mathrm{CC}} \pm 0.21$ & $15.54^{\mathrm{cB}} \pm 0.17$ & $10.78^{\mathrm{cA}} \pm 0.12$ \\
\hline $\operatorname{Ash}(\%)$ & $5.66^{\mathrm{bB}} \pm 0.11$ & $5.60^{\mathrm{aB}} \pm 0.06$ & $3.60^{\mathrm{aA}} \pm 0.11$ & $5.65^{\mathrm{bB}} \pm 0.21$ & $5.60^{\mathrm{a} 0 \mathrm{~B}} \pm 0.23$ & $3.51^{\mathrm{aA}} \pm 0.07$ & $5.00^{\mathrm{aB}} \pm 0.14$ & $5.35^{\mathrm{aB}} \pm 0.21$ & $3.80^{\mathrm{aA}} \pm 0.14$ \\
\hline Crude fibre (\%) & $16.40^{\mathrm{bC}} \pm 0.12$ & $8.25^{\mathrm{bA}} \pm 0.01$ & $12.13^{\mathrm{aB}} \pm 0.01$ & $15.62^{\mathrm{aC}} \pm 0.2$ & $7.28^{\mathrm{aA}} \pm 0.01$ & $12.35^{\mathrm{aB}} \pm 0.01$ & $18.24^{\mathrm{cC}} \pm 0.12$ & $9.24^{\mathrm{cA}} \pm 0.01$ & $13.37^{\mathrm{bB}} \pm 0.03$ \\
\hline Carbohydrates (g) & $21.37^{\mathrm{cA}} \pm 20.25$ & $29.36^{\mathrm{aB}} \pm 3.13$ & $35.91^{\mathrm{cA}} \pm 0.52$ & $19.98^{\mathrm{bA}} \pm 20.96$ & $34.87^{\mathrm{bC}} \pm 0.7$ & $32.24^{\mathrm{bC}} \pm 0.21$ & $13.91^{\mathrm{aA}} \pm 6.68$ & $37.14^{\mathrm{cC}} \pm 24.83$ & $25.6^{\mathrm{aB}} \pm 3.63$ \\
\hline Energy (Kcal) & $401^{\mathrm{aB}} \pm 1.35$ & $409^{\mathrm{aA}} \pm 2.41$ & $378^{\mathrm{aC}} \pm 11.91$ & $407^{\mathrm{bB}} \pm 0.98$ & $416^{\mathrm{bA}} \pm 2.66$ & $383 b^{B} \pm 7.45$ & $408^{\mathrm{bB}} \pm 1.27$ & $419^{\mathrm{bA}} \pm 0.94$ & $385^{\mathrm{bB}} \pm 9.88$ \\
\hline
\end{tabular}

Values are expressed as Mean $\pm \mathrm{SD}$

Means with different notation ( $a, b$ \& $c)$ indicates significant difference at $5 \%$ level of significance between varieties.

Means with different notation (A, B \& C) indicates significant difference at $5 \%$ level of significance between treatments

Table.2 Amino acid content of raw and germinated soybean varieties (mg/100g protein on dry weight basis)

\begin{tabular}{|c|c|c|c|c|c|c|c|c|c|}
\hline \multirow[b]{3}{*}{ Amino acid } & \multicolumn{3}{|c|}{ SL 525} & \multicolumn{3}{|c|}{ SL 744} & \multicolumn{3}{|c|}{ SL 958} \\
\hline & \multicolumn{2}{|c|}{ Non-Germinated } & \multirow[t]{2}{*}{ Germinated } & \multicolumn{2}{|c|}{ Non-Germinated } & \multirow[t]{2}{*}{ Germinated } & \multicolumn{2}{|c|}{ Non-Germinated } & \multirow[t]{2}{*}{ Germinated } \\
\hline & $\begin{array}{l}\text { With seed } \\
\text { coat }\end{array}$ & $\begin{array}{l}\text { Without } \\
\text { seed coat }\end{array}$ & & $\begin{array}{l}\text { With seed } \\
\text { coat }\end{array}$ & $\begin{array}{l}\text { Without seed } \\
\text { coat }\end{array}$ & & With seed coat & $\begin{array}{l}\text { Without seed } \\
\text { coat }\end{array}$ & \\
\hline Lysine (mg/100g) & $4.87^{\mathrm{aA}} \pm 0.06$ & $4.81^{\mathrm{abA}} \pm 0.12$ & $5.32^{\mathrm{aB}} \pm 0.11$ & $4.87^{\mathrm{aB}} \pm 0.01$ & $4.63^{\mathrm{aA}} \pm 0.08$ & $5.10^{\mathrm{aC}} \pm 0.04$ & $5.17^{\mathrm{bA}} \pm 0.01$ & $5.08^{\mathrm{bA}} \pm 0.02$ & $5.70^{\mathrm{bB}} \pm 0.05$ \\
\hline Cysteine (mg/100g) & $0.06^{\mathrm{aA}} \pm 0$ & $0.10^{\mathrm{aB}} \pm 0.01$ & $0.11^{\mathrm{aB}} \pm 0$ & $0.05^{\mathrm{aA}} \pm 0$ & $0.10^{\mathrm{aB}} \pm 0$ & $0.15^{\mathrm{cC}} \pm 0$ & $0.05^{\mathrm{aA}} \pm 0.01$ & $0.11^{\mathrm{aB}} \pm 0$ & $0.13^{\mathrm{bC}} \pm 0$ \\
\hline Methionine (mg/100g) & $0.34^{\mathrm{aB}} \pm 0.01$ & $0.22^{\mathrm{aA}} \pm 0$ & $0.34^{\mathrm{aB}} \pm 0.04$ & $0.46^{\mathrm{cA}} \pm 0$ & $0.36^{\mathrm{bA}} \pm 0.05$ & $0.50^{\mathrm{bB}} \pm 0.04$ & $0.40^{\mathrm{bA}} \pm 0$ & $0.49^{\mathrm{cB}} \pm 0$ & $0.61^{\mathrm{CC}} \pm 0$ \\
\hline Tryptophan (mg/100g) & $0.43^{\mathrm{aA}} \pm 0.04$ & $0.70^{\mathrm{bB}} \pm 0.02$ & $0.91^{\mathrm{bC}} \pm 0.04$ & $0.40^{\mathrm{aA}} \pm 0.02$ & $0.41^{\mathrm{aA}} \pm 0.01$ & $0.60^{\mathrm{aB}} \pm 0.01$ & $0.51^{\mathrm{aA}} \pm 0.05$ & $0.80^{\mathrm{cB}} \pm 0.02$ & $1.11^{\mathrm{cC}} \pm 0.03$ \\
\hline
\end{tabular}

Values are expressed as Mean \pm SD

Means with different notation $(\mathrm{a}, \mathrm{b} \& \mathrm{c})$ indicates significant difference at $5 \%$ level of significance between varieties.

Means with different notation (A, B \& C) indicates significant difference at $5 \%$ level of significance between treatments 
Table.3 Mineral content of raw and germinated soybean varieties (mg/100g on dry weight basis)

\begin{tabular}{|c|c|c|c|c|c|c|c|c|c|}
\hline \multirow[b]{3}{*}{ Mineral content } & \multicolumn{3}{|c|}{ SL 525} & \multicolumn{3}{|c|}{ SL 744} & \multicolumn{3}{|c|}{ SL 958} \\
\hline & \multicolumn{2}{|c|}{ Non-Germinated } & \multirow[b]{2}{*}{ Germinated } & \multicolumn{2}{|c|}{ Non-Germinated } & \multirow[b]{2}{*}{ Germinated } & \multicolumn{2}{|c|}{ Non-Germinated } & \multirow[b]{2}{*}{ Germinated } \\
\hline & $\begin{array}{l}\text { With seed } \\
\text { coat }\end{array}$ & $\begin{array}{l}\text { Without } \\
\text { seed coat }\end{array}$ & & $\begin{array}{l}\text { With seed } \\
\text { coat }\end{array}$ & $\begin{array}{l}\text { Without seed } \\
\text { coat }\end{array}$ & & $\begin{array}{l}\text { With seed } \\
\text { coat }\end{array}$ & $\begin{array}{l}\text { Without seed } \\
\text { coat }\end{array}$ & \\
\hline Calcium (mg/100g) & $145.70^{\mathrm{bA}} \pm 0.78$ & $169.18^{\mathrm{bA}} \pm 20.96$ & $331.81^{\mathrm{bB}} \pm 2.87$ & $115.56^{\mathrm{aA}} \pm 4.07$ & $120.28^{\mathrm{abA}} \pm 17.38$ & $379.11^{\mathrm{bB}} \pm 54.25$ & $114.09^{\mathrm{aA}} \pm 11.1$ & $109.24^{\mathrm{aA}} \pm 7.38$ & $282.99^{\mathrm{aA}} \pm 109.97$ \\
\hline Phosphorus (mg/100g) & $611.45^{\mathrm{aA}} \pm 14.85$ & $609.70^{\mathrm{aA}} \pm 18.03$ & $626.45^{\mathrm{aA}} \pm 9.9$ & $618.70^{\mathrm{aA}} \pm 9.55$ & $633.70^{\mathrm{aA}} \pm 43.49$ & $646.70^{\mathrm{aA}} \pm 26.52$ & $623.20^{\mathrm{aAB}} \pm 20.86$ & $585.95^{\mathrm{aA}} \pm 14.85$ & $649.78^{\mathrm{aB}} \pm 27.57$ \\
\hline Magnesium (mg/100g) & $150.55^{\mathrm{bA}} \pm 2.63$ & $170.96^{\mathrm{bA}} \pm 18.76$ & $236.83^{\mathrm{aB}} \pm 2.94$ & $115.84^{\mathrm{aA}} \pm 4.62$ & $124.22^{\mathrm{aA}} \pm 11.21$ & $264.83^{\mathrm{aB}} \pm 25.41$ & $120.88^{\mathrm{aA}} \pm 8.99$ & $118.22^{\mathrm{aA}} \pm 2.96$ & $224.34^{\mathrm{aA}} \pm 89.0$ \\
\hline Potassium (mg/100g) & $59.37^{\mathrm{aA}} \pm 1.66$ & $59.22^{\mathrm{bA}} \pm 1.38$ & $81.09^{\mathrm{aB}} \pm 0.28$ & $59.24^{\mathrm{aA}} \pm 3.04$ & $56.82^{\mathrm{abA}} \pm 1.94$ & $78.04^{\mathrm{aB}} \pm 5.09$ & $53.99^{\mathrm{aA}} \pm 2.83$ & $52.49^{\mathrm{aA}} \pm 0.07$ & $82.42^{\mathrm{aB}} \pm 5.83$ \\
\hline Zinc (mg/100g) & $3.48^{\mathrm{aA}} \pm 0$ & $3.27^{\mathrm{aA}} \pm 0.35$ & $3.13^{\mathrm{aA}} \pm 0.11$ & $4.21^{\mathrm{bB}} \pm 0.23$ & $3.79^{\mathrm{aAB}} \pm 0.17$ & $3.58^{\mathrm{bA}} \pm 0.03$ & $5.17^{\mathrm{cB}} \pm 0.19$ & $4.63^{\mathrm{bA}} \pm 0.16$ & $5.21^{\mathrm{cB}} \pm 0.07$ \\
\hline
\end{tabular}

Values are expressed as Mean \pm SD

Means with different notation $(\mathrm{a}, \mathrm{b} \& \mathrm{c})$ indicates significant difference at $5 \%$ level of significance between varieties.

Means with different notation (A, B \& C) indicates significant difference at $5 \%$ level of significance between treatments

Table.4 In vitro protein digestibility of raw and germinated soybean varieties

\begin{tabular}{|c|c|c|c|c|c|c|c|c|c|}
\hline \multirow{3}{*}{$\begin{array}{l}\text { In-vitro nutrien } \\
\text { digestibility }\end{array}$} & \multicolumn{3}{|c|}{ SL 525} & \multicolumn{3}{|c|}{ SL 744} & \multicolumn{3}{|c|}{ SL 958} \\
\hline & \multicolumn{2}{|c|}{ Non-Germinated } & \multirow[b]{2}{*}{ Germinated } & \multicolumn{2}{|c|}{ Non-Germinated } & \multirow[b]{2}{*}{ Germinated } & \multicolumn{2}{|c|}{ Non-Germinated } & \multirow[b]{2}{*}{ Germinated } \\
\hline & $\begin{array}{c}\text { With seed } \\
\text { coat }\end{array}$ & $\begin{array}{c}\text { Without seed } \\
\text { coat }\end{array}$ & & $\begin{array}{c}\text { With seed } \\
\text { coat }\end{array}$ & $\begin{array}{c}\text { Without seed } \\
\text { coat }\end{array}$ & & $\begin{array}{c}\text { With seed } \\
\text { coat }\end{array}$ & $\begin{array}{c}\text { Without } \\
\text { seed coat }\end{array}$ & \\
\hline $\begin{array}{l}\text { In-vitro proteir } \\
\text { digestibility }(\%)\end{array}$ & $79.79^{\mathrm{aA}} \pm 2.19$ & $79.84^{\mathrm{aA}} \pm 0.35$ & $80.04^{\mathrm{aA}} \pm 0.19$ & $81.53^{\mathrm{bA}} \pm 0.58$ & $84.74^{\mathrm{cA}} \pm 2.44$ & $84.91^{\mathrm{bA}} \pm 1.27$ & $83.38^{\mathrm{cB}} \pm 1.69$ & $71.93^{\mathrm{bA}} \pm 0.45$ & $86.61^{\mathrm{cC}} \pm 1.55$ \\
\hline
\end{tabular}

Values are expressed as Mean \pm SD

Means with different notation ( $\mathrm{a}, \mathrm{b} \& \mathrm{c}$ ) indicates significant difference at $5 \%$ level of significance between varieties.

Means with different notation (A, B \& C) indicates significant difference at 5\% level of significance between treatments

Table.5 Anti-nutritional factors of raw and germinated soybean varieties

\begin{tabular}{|c|c|c|c|c|c|c|c|c|c|}
\hline \multirow[t]{3}{*}{ Anti-nutritional factors } & \multicolumn{3}{|c|}{ SL 525} & \multicolumn{3}{|c|}{ SL 744} & \multicolumn{3}{|c|}{ SL 958} \\
\hline & \multicolumn{2}{|c|}{ Non-Germinated } & \multirow[b]{2}{*}{ Germinated } & \multicolumn{2}{|c|}{ Non-Germinated } & \multirow[b]{2}{*}{ Germinated } & \multicolumn{2}{|l|}{ Non-Germinated } & \multirow[b]{2}{*}{ Germinated } \\
\hline & With seed coat & $\begin{array}{l}\text { Without seed } \\
\text { coat }\end{array}$ & & $\begin{array}{l}\text { With seed } \\
\text { coat }\end{array}$ & $\begin{array}{l}\text { Without seed } \\
\text { coat }\end{array}$ & & With seed coat & $\begin{array}{l}\text { Without seed } \\
\text { coat }\end{array}$ & \\
\hline Total phenol (mg/100g) & $224.46^{\mathrm{aB}} \pm 4.07$ & $225.18^{\mathrm{aB}} \pm 1.02$ & $85.61^{\mathrm{aA}} \pm 3.05$ & $185.61^{\mathrm{bB}} \pm 0.1$ & $182.01^{\mathrm{bB}} \pm 1.02$ & $89.21^{\mathrm{aA}} \pm 6.1$ & $169.06^{\mathrm{aB}} \pm 3.05$ & $161.87^{\mathrm{aB}} \pm 1.02$ & $80.58^{\mathrm{aA}} \pm 8.14$ \\
\hline $\begin{array}{l}\text { Trypsin Inhibitor (TIU/g of } \\
\text { protein) }\end{array}$ & $14.21^{\mathrm{cB}} \pm 0.02$ & $14.51^{\mathrm{bC}} \pm 0.01$ & $11.49^{\mathrm{aA}} \pm 0.02$ & $13.75^{\mathrm{bB}} \pm 0.01$ & $14.10^{\mathrm{aC}} \pm 0.02$ & $11.94^{\mathrm{bA}} \pm 0.03$ & $13.47^{\mathrm{aB}} \pm 0.01$ & $14.15^{\mathrm{aC}} \pm 0.01$ & $12.54^{\mathrm{cA}} \pm 0.04$ \\
\hline
\end{tabular}

Values are expressed as Mean \pm SD

Means with different notation $(\mathrm{a}, \mathrm{b} \& \mathrm{c})$ indicates significant difference at $5 \%$ level of significance between varieties.

Means with different notation (A, B \& C) indicates significant difference at $5 \%$ level of significance between treatments. 
Germination is highly recommended costeffective for increasing the bioactive compounds and amino acid content in soybean seeds. The value-added bioactive compounds can be resulted due to the biochemical changes observed in the soybean seeds. It was also noted that the amino acid, free and total phenolic compounds and isoflavone content intensified by germination. The amino acid content was prominently influenced by these compounds. Considering the high amino acid content and with the potential health benefits; in order to obtain functional food, germination can be an appropriate process with its beneficial effects in chronic degenerative diseases, such as cancer and obesity. (Guzman et al., 2017)

\section{Mineral content}

Soybean seeds with different varieties were given different treatments which were analyzed for potassium, calcium, phosphorus, magnesium and zinc as depicted in Table 3. The significant increase in mineral content was observed with germination. Highest and lowest content of potassium was reported in SL 958 with different treatments where G reported highest content of $82.42 \mathrm{mg}$ and $52.49 \mathrm{mg}$ reported to be the lowest in NGWSC treated soybean. Calcium of SL 744 in $\mathrm{G}(379.11 \mathrm{mg})$ was highest and lowest in NGWSC of SL 958 with $109.24 \mathrm{mg}$. In G, SL 958 obtained highest phosphorus content of $649.78 \mathrm{mg}$ whereas lowest in NGWSC with $585.95 \mathrm{mg}$. The magnesium content in SL 744 was reported highest in $264.83 \mathrm{mg}$ of $\mathrm{G}$ seeds and lowest in NGSC with $115.84 \mathrm{mg}$. No significant difference was observed in highest content of zinc in G and NGSC of SL 958. Rahman et al., (2016) reported that germinated soy flour contained $368 \mathrm{mg} / 100 \mathrm{gm}$ calcium, 496mg/100gm phosphorous and $16.45 \mathrm{mg} / 100 \mathrm{gm}$ iron. Luo et al., (2013) studied that germination reduces the availability of zinc from faba bean and soybean. There was an increase in the availability of calcium from faba bean, soybean, and rice with availability of manganese from soybean (14.4\%) and rice $(43 \%)$. Thus, germination could be an appropriate food-based strategy to increase the iron content with other minerals from food grains.

\section{In vitro protein digestibility}

In vitro protein digestibility of germinated soybean seeds (Table 4) increased significantly from raw seeds such that the germinated seeds in SL 958 reported the highest in vitro protein digestibility i.e. 86.61 percent as compared to NGWSC which reported the lowest with 71.93 percent. A significant increase was observed in the in vitro protein digestibility of white beans, black beans and pigeon beans after germination (Sangronis and Machado, 2007). Urbano et al., (2005) reported that in-vitro protein digestibility was slightly decreased with longer germination periods compared with the raw pea flour diet $(2.3 \%$ and $7.9 \%)$ in G3 DNL (three day germination) and G6 DNL (six day germination) respectively and between germination periods no significant difference result was found.

\section{Anti-nutritional components}

The anti-nutritional factors like trypsin inhibitors and total phenol content (Table 5) decreased with germination, in SL 525 lowest trypsin inhibitor content was reported i.e. 11.49 TIU per $\mathrm{g}$ of protein whereas in NGWSC treated seeds obtained the highest content of 14.51 TIU per g of protein. Total phenol content in G of SL 958 was lowest whereas NGWSC of SL 525 was highest with 80.58 and $225.18 \mathrm{mg}$ respectively. Effects of traditional processing methods on the nutritional and anti-nutritional properties of soybean were analysed by Pele et al., (2016). Soybeans were subjected to various handling strategies which were mainly sun drying and 
processing. Sample A was considered as the controlled sample where the soybean seeds were subjected to sun for drying and then milled. For sample B, soybean was drenched for 24 hours then it was sun dried and processed. For test $\mathrm{C}$, it was almost similar to sample B but it was soaked for 12 hours instead of 24 hours which was later de-hulled, sun dried and further subjected to processing. For the last sample D, the soybeans were sprouted for 120 hours, then they were sun dried and later processed. The anti-nutritional properties of the test samples demonstrated that phytic acid content ranged between 5.45 percent to 8.05 percent which essentially diminish in test B, C and D. The tannin content extended from 19.23 percent to 25.23 $\mathrm{mg} / 100 \mathrm{~g}$ while the protease inhibitor ran from 4.91 to 7.09 percent with a noteworthy lessening in test B, C and D. In the end, it was recorded that there was increase in the nutritional properties of soybeans because of traditional processing methods. Also, traditional processing method remarkably lessened the anti-nutritional properties of soybeans which also led to maximizing the bioavailability of its nutrients.

$\mathrm{Xu}$ and Chang (2008) reported that $73.4 \%$ of the phenolic antioxidant compounds are found in the seed coat part of the soybean seeds. Kayembe and Rensburg (2013) reported that germination, soaking and de-hulling of the seeds may lower the trypsin inhibitor levels. However, there were no changes in in vitro protein digestibility (IVPD). (Rahman et al., 2016) observed that raw soy flour contains some anti-nutritional factors which were removed by germination process. Also, germinated flour can be stored up to six months at ambient temperature and was found to be microbiologically safe for human consumption. The germination resulted in nutritionally enriched soy flour to that of nongerminated soy flour and could be used as raw material or ingredient for making bakery products.
Vagadia et al., (2017) reviewed the inactivation methods of trypsin inhibitor in soybean. Soybeans contain a variety of bioactive anti-nutritional compounds including protease trypsin inhibitors, phytic acid and isoflavones that gives undesirable physiological effects and hinder its nutritional quality. The processing methods for inactivation of soybean trypsin inhibitor are physical treatments and conventional treatments. In physical treatments, under the influence of high temperatures or mechanical stress the chemical structure is changed. Therefore, most treatments involve heating the soybean samples for a certain amount of time. The heat energy helps in breaking down the physical structure of the molecule which further makes it easy for the digestion of enzyme. In conventional treatments, the thermal inactivation of trypsin inhibitors depends mainly on the time period, temperature with the water content in the sample. Some of the common methods used to eliminate the trypsin inhibitor are forced conventional drying and roasting. Furthermore, quite a few studies have observed that soaking the seed for 12-14 hours alone cannot manage the trypsin inhibitor activity of the soybean seed but if the soaked seed is cooked it results in 82 percent of its activity. Lastly, the studies have illustrated that germination of soybean seeds decrease the trypsin inhibitor activity and increases the in-vitro digestibility of soybean protein.

\section{References}

Akeson, W., E. and Stachman, M. A. 1964. A pepsin-pancreatin digest index of protein quality evaluation. Journal of Nutrition 83: 257-61.

AOAC, 2000. Official methods of analysis. Association of official analytical chemists, $16^{\text {th }}$ edition, Washington, DC.

Ari, M. M., Ayanwale, B. A., Adama, T. Z. and Olatunji, 2012. Evaluation of the 
chemical composition and anti-nutritional factors (ANFs) levels of different thermally processed soybeans. Asian Journal of Agricultural Research6:91-98.

Booth, V. H., 1971. Problems in determination of FDNB- available lysine. Journal of the Science of Food Agriculture. 22: 658-66.

Carpenter, K. J., 1960. The estimation of available lysine in animal protein foods. Journal of Biochemistry 77: 604-10.

Cho, S. Y., Lee, Y. N. and Park, H. J., 2009. Optimization of ethanol extraction and further purification of isoflavones from soybean sprout cotyledon. Food Chemistry 117: 312-17.

Concon, J. M., 1975. Rapid and simple method for demonstration of tryptophan in cereal grains. Analytical Biochemistry 67: 20619.

Ghavidel, R. A. and Prakash, J., 2007. The impact of germination and dehulling on nutrients, antinutrients, in vitro iron and calcium bioavailability and in vitro starch and protein digestibility of some legume seeds. Journal of Food Science and Nutrition 40: 1292-99.

Goel, R., Kaur, A. and Singh, J., 2018. Varietal evaluation of soybean for tofu making. Asian Journal of Dairy Food Research 37: 81-84.

Guzman-Ortis, F. A., Martínez, M. S., Valverde, M. E., Rodríguez-Aza, Y., Berríos, J. D. and Mora-Escobedo. R., 2017. Profile analysis and correlation across phenolic compounds, isoflavones and antioxidant capacity during germination of soybeans (Glycine $\max$ L.). Journal of Food Science. 15: 516-24.

Hallen, E., Ibanoglu, S. and Ainsworth. P., 2004. Effect of fermented/germinated cowpea flour addition on the rheological and baking properties of wheat flour. Journal of Food Engineering 63: 177-84.

Horn, M. J., Jones, D., B. and Blum, A. E., 1946. Calorimetric determination of methionine in proteins and foods. Journal of Biological Chemistry. 166: 313-20.

Kayembe, N. C. and Rensburg, J. V., 2013.
Germination as a processing technique for soybeans in small-scale farming Department of Animal and Wildlife Sciences, University of Pretoria, Pretoria 0002, South Africa. South African Journal of Animal Science. 43: 1-7.

Liddell, H. P. and Saville, B., 1959. Calorimetric determination of cysteine. Analyst 84: 188-90.

Luo, Y. W., Xie, W. H., Jin, X. X., Wang, Q. and He, Y. J., 2013. Effects of germination on iron, zinc, calcium, manganese, and copper availability from cereals and legumes. Journal of Food Science 12: 22-26.

Martino, H. S., Carvalho, A. W., Silva, C. O., Dantas, M. I., Natal, D. I., Ribeiro, S. M. and Costa N M 2011. Heat-treated hull flour does not affect iron bioavailability in rats. Archivos Latinoamericanos de Nutricion 61: 135-42.

Nwosu, J. N., Owuamanam, C. I., Omeire, G. C. and Eke, C. C. 2014. Quality parameters of bread produced from substitution of wheat flour with cassava flour using soybean as an improver. American Journal of Research Community 2: 99-118.

Osman, M. A., 2007. Effect of different processing methods, on nutrient composition, antinutritional factors, and in vitro protein digestibility of Dolichos lablab bean sweet. Journal of Nutrition 6: 299-303.

Pele, G. I., Ogunsua, A. O., Adepeju, A. B., Esan, Y. O. and Oladiti, E. O., 2016. Effects of processing methods on the nutritional and anti-Nutritional properties of soybeans (Glycine max). African Journal of Food Science Technology. 7(1): 9-12.

Rahman, M. M., Shahjadee, U. F., Rupa, A. Z. and Hossain, M. N., 2016. Nutritional and microbiological quality of germinated soy flour. Bangladesh Journal Science Indian Research 51: 167-74.

Ramadan, E. A., 2012. Effect of processing and cooking methods on the chemical composition, sugars and phytic acid of 
soybeans. Food Public Health. 2: 11-15.

Roy, D. N. and Rao, P. S. 1971. Evidence, isolation, precipitation and some properties of trypsin inhibitor in Lathyrus sativus. Journal of Agricultural Food Chemistry 19: 257-59.

Sangronis, E. and Machado, C. J. 2007. Influence of germination on the nutritional quality of Phaseolus vulgaris and Cajanuscajan. Journal Food Science Agriculture Technology 40: 116-20.

Serrem, C., Koch, H. and Taylor, J., 2011. Nutritional quality, sensory quality and consume acceptability of sorghum and bread wheat biscuits fortified with defatted soy flour. International Journal of Food Science Technology 46: 74-83.

Singh, A. K., Kadam, D. M., Sexena, M. and Singh, R. P., 2009. Efficacy of defatted soy flour supplement in gulabjamun. African Journal of Biochemistry Research 3: $130-13$.

Singh, J., 2016. Effect of storage on germination and viability of soybean (Glycine max) and Niger (Guizotia abyssinica) seeds. International Journal of Current Microbiology and Applied Sciences 5: 484-91.

Torres, N., Villalvazo, I. T. and Tovar, A. R. 2006 Regulation of lipid metabolism by soy protein and its implication in diseases mediated by lipid disorders. Journal of
Nutritional Biochemistry 17: 365-73.

Ugwuona, F. U., Ogara, J. I. and Awogbenja, M. D., 2012. Chemical and sensory quality of cakes formulated with wheat, soybean and cassava flours. Indian Journal of Life Sciences 1: 1-6.

Urbano, G., Lopez, M., Frejnagel, S., Gomez, E., Porres, J. M., Frias, J., Vidal, C. and Aranda, P. 2005. Nutritional assessment of raw and germinated pea (Pisumsativum L.) protein and carbohydrate by in vitro and in vivo techniques. Nutrition 21: 23039.

Vagadia, B. H., Vanga, S. K. and Raghavan, V., 2017. Inactivation methods of soybean trypsin inhibitor- A review. Trends in Food Science and Technology 64: 11525.

Warle, B. M., Riar, C. S., Gaikwad, S. S. and Mane, V. A., 2015. Effect of germination on nutritional quality of soybean (glycine max). Journal of Environmental Science Toxicology and Food Technology 9: 1316.

$\mathrm{Xu}$, B. and Chang, S. K. 2008. Antioxidant capacity of seed coat, dehulled bean, and whole black soybeans in relation to their distributions of total phenolics, phenolic acids, anthocyanins, and isoflavones. Journal of Agricultural and Food Chemistry 56: 8365-73.

\section{How to cite this article:}

Harmeen Kaur and Navjot Kaur. 2019. Effect of Germination on the Nutritional and AntiNutritional Composition of Soy Bean (Glycine max). Int.J.Curr.Microbiol.App.Sci. 8(08): 582-591. doi: https://doi.org/10.20546/ijcmas.2019.808.070 